\title{
In vitro effect of globotriaosylceramide on electron transport chain complexes and redox parameters
}

\section{RAFAELA M. ALVARIZ ${ }^{1,2}$, ISABEL T.D.S. MOREIRA ${ }^{3}$, GABRIELA K. CURY ${ }^{2}$, CARMEN R. VARGAS ${ }^{4,5,6}$ and ALETHÉA G. BARSCHAK ${ }^{1}$}

\author{
${ }^{1}$ Programa de Pós-Graduação em Patologia, Universidade Federal de Ciências da Saúde de Porto \\ Alegre/UFCSPA, Rua Sarmento Leite, 245, 90050-170 Porto Alegre, RS, Brazil \\ ${ }^{2}$ Gerência de Laboratórios, Universidade Federal de Ciências da Saúde de Porto Alegre/ \\ UFCSPA, Rua Sarmento Leite, 245, 90050-170 Porto Alegre, RS, Brazil \\ ${ }^{3}$ Universidade Federal de Ciências da Saúde de Porto Alegre/UFCSPA, Rua \\ Sarmento Leite, 245, 90050-170 Porto Alegre, RS, Brazil \\ ${ }^{4}$ Serviço de Genética Médica, Hospital de Clínicas de Porto Alegre/HCPA, Rua \\ Ramiro Barcelos, 2350, 90035-903 Porto Alegre, RS, Brazil \\ ${ }^{5}$ Programa de Pós-Graduação em Ciências Biológicas: Bioquímica/UFRGS, Rua \\ Ramiro Barcelos, 2600, 90035-003 Porto Alegre, RS, Brazil \\ ${ }^{6}$ Programa de Pós-Graduação em Ciências Farmacêuticas/UFRGS, Av. Ipiranga, 2752, 90610-000 Porto Alegre, RS, Brazil
}

Manuscript received on January 9, 2019; accepted for publication on March 13, 2019

\begin{abstract}
How to cite: ALVARIZ RM, MOREIRA ITDS, CURY GK, VARGAS CR AND BARSCHAK AG. 2019. In vitro effect of globotriaosylceramide on electron transport chain complexes and redox parameters. An Acad Bras Cienc 91: e20181373. DOI 10.1590/0001-3765201920181373.
\end{abstract}

\begin{abstract}
Fabry disease (FD) is an X-linked inherited disease and occurs due to mutations in GLA gene that encodes the $\alpha$-galactosidase enzyme. Consequently, there is an accumulation of enzyme substrates, namely globotriaosylceramide (GB3). FD is a multisystemic disease, caused by storage of GB3 in vascular endothelia, with significant renal, cardiac and vascular involvement. The aim of this work was to evaluate the in vitro effect of GB3 on electron transport chain complexes (ETC) and redox parameters. Biochemical biomarkers were determined in homogenates of cerebral cortex, kidneys and liver of Wistar rats in the presence or absence of GB3 at concentrations of 3, 6, 9 and $12 \mathrm{mg} / \mathrm{L}$. We found that GB3 caused an increase of ETC complexes II and IV activities, increased production of reactive species and decreased superoxide dismutase enzyme activity in homogenates of cerebral cortex. As well also increased production of reactive species and superoxide dismutase activity in kidney homogenates. The results obtained in our work suggest that GB3 interferes in ETC complexes II and IV activities, however, the magnitude of this increase seems to be too low to present a physiologically importance. However, the imbalance in cellular redox state indicating that these alterations may be involved in the pathophysiology of FD, mainly in renal and cerebral manifestations.
\end{abstract}

Key words: electron transport chain, fabry disease, globotriaosylceramide, GB3, oxidative stress, reactive species.

\footnotetext{
Correspondence to: Alethéa Gatto Barschak

E-mail: alethea@ufcspa.edu.br / aletheagatto@gmail.com

ORCid: https://orcid.org/0000-0002-3399-5652
} 


\section{INTRODUCTION}

Fabry disease (FD) is an X-linked genetic disorder caused by a deficiency of the lysosomal enzyme $\alpha$-galactosidase A. This defect causes the accumulation of glycosphingolipids, class of glycolipids formed by ceramide and one or more carbohydrates, particularly the globotriaosylceramide (GB3), inside heart, kidney, brain, skin, eyes and vascular tissues (Desnick et al. 2001). Clinical manifestations include acroparesthesia, angiokeratomas, cornea verticillata, myocardial hypertrophy, arrhythmias, renal impairment and gastrointestinal disorders (Germain 2010).

In addition to clinical symptoms, definitive diagnosis of FD has been made through the determination of $\alpha$-galactosidase A enzymatic activity and through plasma quantification of GB3 levels (Desnick et al. 2001). Kruger and coworkers, in a study involving 209 FD patients, found plasma concentrations of GB3 ranging from $2.9-13.3 \mathrm{mg} / \mathrm{L}$ (Krüger et al. 2010).

Some evidence demonstrate that oxidative stress may be involved in pathophysiology of FD. Shen and coworkers, have shown that the excess of intracellular GB3 increases the production of reactive oxygen species (ROS) and induces oxidative stress (Shen et al. 2008b). Biancini and coworkers, in a study involving FD patients undergoing treatment with enzyme replacement therapy, found a positive correlation between plasma GB3 concentrations and MDA levels and carbonyl groups, indicating that GB3 could be an inducer of lipid peroxidation and protein damage (Biancini et al. 2012).

The electron transport chain (ETC) consists of complexes I, II, III and IV being, respectively, NADH dehydrogenase, succinate dehydrogenase, cytochrome b-c $\mathrm{c}_{1}$ and cytochrome oxidase. In addition to these complexes, ETC presents coenzyme Q and cytochrome $\mathrm{c}$ as mobile elements among the complexes (Nelson and Cox 2013). In the process of electron transport, the complexes take protons from the matrix and release them inside the intermembrane space, creating a proton gradient. This proton gradient leads to ATP production, which occurs when they return to the interior of the matrix. Blocking electron transfer or increasing activity in any of the complexes may have pathological consequences, such as exacerbated increase in proton-motive force or a decrease in intracellular ATP levels (Figueira et al. 2013). Interference at any point in the ETC can trigger events that lead to irreversible cell damage and even cell death (Lieberman and Marks 2009).

It has not been yet fully understood how the cellular routes affected in lysosomal disease are interconnected, as well as how they affect the viability of cells in different tissues. In this context, the present study aimed to evaluate the in vitro effect of the main metabolite accumulated in FD, the GB3 on ETC complexes and the redox parameter (reactive species formation, antioxidant enzymes activity and lipoperoxidation) in the cerebral cortex, kidneys and liver of Wistar rats.

\section{MATERIALS AND METHODS}

\section{ANIMALS}

Thirty days old male Wistar rats (Rattus norvegicus) maintained in a controlled environment and temperature $\left(22 \pm 1^{\circ} \mathrm{C}\right)$, water and fed ad libitum, and $12 \mathrm{~h}$ light-dark cycles from UFCSPA's Central Animal House were used. All animal $(n=6)$ procedures were approved by the ethics committee on animal use of the Universidade Federal de Ciências da Saúde de Porto Alegre (UFCSPA), under protocol number 107/13.

\section{TISSUE PREPARATION PROTOCOL}

Euthanasia of animals was performed through decapitation to preserve the brain and quickly dissected on ice. 


\section{TISSUES HOMOGENATE INCUBATION WITH GB3}

For the determination of ETC complexes and oxidative stress parameters, cerebral cortex and kidneys were homogenized $(1: 20, \mathrm{v} / \mathrm{v})$ in a TRIS buffer, $\mathrm{pH}$ 7.4. The homogenate was centrifuged at $600 \mathrm{~g}$ for 10 minutes to remove cell debris. Aliquots of the supernatant were made and these were kept frozen $\left(-80^{\circ} \mathrm{C}\right)$ until determinations. The samples underwent three freeze-thaw cycles for the disruption of mitochondrial membranes and exposure of the catalytic sites of ETC enzymes. The parameters were determined in homogenate pre-incubated for 60 minutes at $37^{\circ} \mathrm{C}$ in the absence (control group) or presence (test group) of GB3 at concentrations of 3, 6, 9 and $12 \mathrm{mg} / \mathrm{L}$, according to the plasma concentration in a study of Kruger et al. (2010).

\section{DETERMINATION OF THE I-IV COMPLEXES OF THE ETC}

The activities of the complexes I, II, III e IV were determined according to Spinazzi et al. (2012). The results were expressed as nmol/min $\mathrm{mg}$ of proteins.

\section{PROTEIN DETERMINATION}

Proteins were determined by the Lowry et al. (1951) method using bovine serum albumin as standard.

\section{SUPEROXIDO-DISMUTASE (SOD) ACTIVITY}

SOD activity was evaluated by quantifying the inhibition of superoxide dependent autoxidation of epinephrine, verifying the absorbance of the samples at $480 \mathrm{~nm}$ according to Misra and Fridovich (1972). SOD activity was expressed as the amount of enzyme that inhibits the oxidation of epinephrine by $50 \%$, which is equal to 1 unit. The data were expressed as Units/mg protein.

\section{CATALASE (CAT) ACTIVITY}

CAT activity was assayed according to Aebi (1984) by measuring the absorbance decrease at $240 \mathrm{~nm}$ in a reaction medium containing $20 \mathrm{mM} \mathrm{H}_{2} \mathrm{O}_{2}, 0.1 \%$ Triton $\mathrm{X}-100$ and $10 \mathrm{mM}$ potassium phosphate buffer, $\mathrm{pH}$ 7.0. One CAT unit is defined as $1 \mu \mathrm{mol}$ of hydrogen peroxide consumed per minute and the specific activity is reported as Units/mg protein.

\section{DCF ASSAY}

ROS and nitrogen reactive species (RNS) production was determined according to the method described by LeBel et al. (1992). Briefly, $20 \mu \mathrm{L}$ of the sample were incubated at $37^{\circ} \mathrm{C}$, in the dark, for $30 \mathrm{~min}$, with the addition of $175 \mu \mathrm{L}$ of PBS buffer and $5 \mu \mathrm{L}$ of DCF diacetate in a 96well plate. DCF is cleaved by cellular esterases and form $\mathrm{H}_{2} \mathrm{DCF}$ that is oxidized by reactive species, which are present in the sample, producing a fluorescent compound, the DCF. DCF oxidation was fluorimetrically measured by using a $480 \mathrm{~nm}$ excitation and a $520 \mathrm{~nm}$ emission wavelength. The protein concentration of the samples were standardized at $1 \mathrm{mg} / \mathrm{mL}$.

\section{THIOBARBITURIC ACID REACTIVE SUBSTANCES} (TBARS) MEASUREMENT

Reactive species react with membrane lipids causing lipoperoxidation, with consequent formation of malondialdehyde (MDA), which was quantified by the method described by Ohkawa et al. (1979). MDA reacts with thiobarbituric acid under heating to form a pink-colored compound measured in a spectrophotometer at $535 \mathrm{~nm}$. The coloration is proportional to the formed malondialdehyde. The results were expressed as nmol TBARS/mg protein.

\section{MEASUREMENT OF TOTAL THIOL CONTENT (SULFHYDRYLS)}

Total thiol content was measured by method of Aksenov and Markesbery (2001), which is based on reduction of dithionitrobenzoic acid (DTNB) by thiols, generating a yellow derivative (TNB) read spectrophotometrically at $412 \mathrm{~nm}$. The results were expressed as nmol TNB / mg protein. 


\section{STATISTICAL ANALYSIS}

Data from the experiments were statistically analyzed by one-way analysis of variance (ANOVA) followed by the Tukey test, where the $F$ value was significant. Values of $\mathrm{p}<0.05$ were considered significant. For statistical analysis, the Statistical Package for Social Sciences (SPSS) software was used.

\section{RESULTS}

ETC

The ETC complexes activity was individually determined in the homogenates of cerebral cortex, liver and kidneys of Wistar rats pre-incubated with GB3. Complex II activity in kidney was significantly increased in the presence of GB3 at concentrations of $3 \mathrm{mg} / \mathrm{L}(\mathrm{p}=0.004)$ and $9 \mathrm{mg} / \mathrm{L}$ $(p=0.041)$. An increase of complex IV activity in kidney at GB3 concentrations of $6 \mathrm{mg} / \mathrm{L}(\mathrm{p}=$ $0.005)$ and $12 \mathrm{mg} / \mathrm{L}(\mathrm{p}=0.033)$ was also observed. ETC complexes activity in cerebral cortex and liver homogenate was not affected by GB3 exposition (Table I).

\section{REDOX STATE}

The DCF assay was performed to determine the production of reactive species. The production of reactive species also demonstrated a significant increase compared to the control group, at concentrations of $6 \mathrm{mg} / \mathrm{L}(\mathrm{p}<0.001), 9 \mathrm{mg} / \mathrm{L}(\mathrm{p}<$ $0.001)$ and $12 \mathrm{mg} / \mathrm{L}(\mathrm{p}<0.001)$ of GB3 in cerebral cortex homogenate (Fig. 1e). The results showed a significant increase of reactive species compared to the control group, at concentrations of $3 \mathrm{mg} / \mathrm{L}(\mathrm{p}=$ $0.01), 6 \mathrm{mg} / \mathrm{L}(\mathrm{p}<0.001), 9 \mathrm{mg} / \mathrm{L}(\mathrm{p}<0.001)$ and $12 \mathrm{mg} / \mathrm{L}(\mathrm{p}<0.001)$ of GB3 in kidney homogenate (Fig. 2e). The production of reactive species in liver (Fig. 3e) homogenate was not altered by GB3 exposition.
A significant decrease at SOD activity of 6 $\mathrm{mg} / \mathrm{L}(\mathrm{p}<0.001), 9 \mathrm{mg} / \mathrm{L}(\mathrm{p}<0.001)$ and $12 \mathrm{mg} / \mathrm{L}$ $(\mathrm{p}<0.001)$ of GB3 in cerebral cortex (Fig. 1b) homogenate was demonstrated.

In the kidney homogenate there was an increase in SOD activity at concentrations of $6 \mathrm{mg} / \mathrm{L}(\mathrm{p}<$ $0.001), 9 \mathrm{mg} / \mathrm{L}(\mathrm{p}<0.001)$ and $12 \mathrm{mg} / \mathrm{L}(\mathrm{p}<0.001)$ (Fig. 2b). However, no changes were observed in CAT activity (Fig. 2a).

No significant changes in sulphydril content or MDA levels were observed in cerebral cortex, kidney and liver homogenates pre-incubated with GB3 when compared to the control group (Fig. 1c, $\mathrm{d}, 2 \mathrm{c}, \mathrm{d}, 3 \mathrm{c}$ and $\mathrm{d}$ ).

\section{DISCUSSION}

There are few studies in literature evaluating oxidative stress in FD (Shen et al. 2008a, Biancini et al. 2016) and no work evaluating ETC activity in this disease. In this sense, our work aims to analyze, in vitro, the effect of the main metabolite accumulated in FD, GB3, on ETC protein complexes, production of reactive species, lipoperoxidation and antioxidant enzymes CAT and SOD.

Small amounts of ROS are generated in the normal course of oxidative phosphorylation. The production of superoxide radical $\left(\mathrm{O}_{2}{ }^{--}\right)$ occurs mainly inside the mitochondria. During energy transduction, a small number of electrons prematurely "leak", forming a superoxide free radical, which has been implicated in the pathophysiology of a variety of diseases (Valko et al. 2007, Poyton et al. 2009, Cherry and Piantadosi 2015).

Oxidative stress has recently been shown to act on several inborn errors of metabolism, suggesting that it may be involved in neurological damage observed in these diseases. However, the mechanism responsible for oxidative stress in inborn errors of metabolism is not yet fully 
TABLE I

In vitro effect of GB3 treatment on complexes I, II, III and IV activity in each animal organ.

\begin{tabular}{|c|c|c|c|c|}
\hline ORGAN & COMPLEX & TREATMENT & $\begin{array}{c}\text { MEAN } \pm \text { SD } \\
(\mathrm{nmol} / \mathrm{min} \mathrm{mg} \text { of proteins })\end{array}$ & $p$ \\
\hline \multirow{19}{*}{ CORTEX } & I & CONTROL & $8.62 \pm 0.54$ & 1.00 \\
\hline & & $3 \mathrm{mg} / \mathrm{mL}$ & $7.74 \pm 0.61$ & 1.00 \\
\hline & & $6 \mathrm{mg} / \mathrm{mL}$ & $8.49 \pm 0.93$ & 1.00 \\
\hline & & $9 \mathrm{mg} / \mathrm{mL}$ & $8.54 \pm 0.83$ & 1.00 \\
\hline & & $12 \mathrm{mg} / \mathrm{mL}$ & $8.56 \pm 0.80$ & 1.00 \\
\hline & II & CONTROL & $19.7 \pm 1.1$ & 1.00 \\
\hline & & $3 \mathrm{mg} / \mathrm{mL}$ & $18.7 \pm 1.4$ & 1.00 \\
\hline & & $6 \mathrm{mg} / \mathrm{mL}$ & $17.7 \pm 0.59$ & 0.765 \\
\hline & & $9 \mathrm{mg} / \mathrm{mL}$ & $19.2 \pm 0.99$ & 1.00 \\
\hline & & $12 \mathrm{mg} / \mathrm{mL}$ & $20.3 \pm 1.2$ & 1.00 \\
\hline & III & CONTROL & $135 \pm 10.3$ & 1.00 \\
\hline & & $3 \mathrm{mg} / \mathrm{mL}$ & $158 \pm 14.1$ & 1.00 \\
\hline & & $6 \mathrm{mg} / \mathrm{mL}$ & $155 \pm 9.7$ & 0.329 \\
\hline & & $9 \mathrm{mg} / \mathrm{mL}$ & $131 \pm 11.5$ & 1.00 \\
\hline & & $12 \mathrm{mg} / \mathrm{mL}$ & $132 \pm 10.5$ & 1.00 \\
\hline & IV & CONTROL & $330 \pm 31.6$ & 1.00 \\
\hline & & $3 \mathrm{mg} / \mathrm{mL}$ & $315 \pm 28.5$ & 1.00 \\
\hline & & $6 \mathrm{mg} / \mathrm{mL}$ & $338 \pm 17.4$ & 1.00 \\
\hline & & $9 \mathrm{mg} / \mathrm{mL}$ & $323 \pm 21.5$ & 1.00 \\
\hline \multirow{21}{*}{ KIDNEY } & & $12 \mathrm{mg} / \mathrm{mL}$ & $321 \pm 25.6$ & 1.00 \\
\hline & I & CONTROL & $9.68 \pm 1.0$ & 1.00 \\
\hline & & $3 \mathrm{mg} / \mathrm{mL}$ & $9.05 \pm 0.70$ & 1.00 \\
\hline & & $6 \mathrm{mg} / \mathrm{mL}$ & $10.2 \pm 1.3$ & 0.385 \\
\hline & & $9 \mathrm{mg} / \mathrm{mL}$ & $10.3 \pm 1.2$ & 1.00 \\
\hline & & $12 \mathrm{mg} / \mathrm{mL}$ & $9.88 \pm 1.3$ & 1.00 \\
\hline & II & CONTROL & $17.3 \pm 1.0$ & 1.00 \\
\hline & & $3 \mathrm{mg} / \mathrm{mL}$ & $19.7 \pm 1.0$ & 0.004 \\
\hline & & $6 \mathrm{mg} / \mathrm{mL}$ & $19.0 \pm 0.54$ & 0.122 \\
\hline & & $9 \mathrm{mg} / \mathrm{mL}$ & $18.7 \pm 0.74$ & 0.041 \\
\hline & & $12 \mathrm{mg} / \mathrm{mL}$ & $18.6 \pm 0.84$ & 1.00 \\
\hline & III & CONTROL & $170 \pm 16.2$ & 1.00 \\
\hline & & $3 \mathrm{mg} / \mathrm{mL}$ & $161 \pm 18.4$ & 1.00 \\
\hline & & $6 \mathrm{mg} / \mathrm{mL}$ & $172 \pm 13.4$ & 1.00 \\
\hline & & $9 \mathrm{mg} / \mathrm{mL}$ & $164 \pm 10.6$ & 1.00 \\
\hline & & $12 \mathrm{mg} / \mathrm{mL}$ & $151 \pm 15.4$ & 1.00 \\
\hline & IV & CONTROL & $476 \pm 24.4$ & 1.00 \\
\hline & & $3 \mathrm{mg} / \mathrm{mL}$ & $503 \pm 25.1$ & 1.00 \\
\hline & & $6 \mathrm{mg} / \mathrm{mL}$ & $555 \pm 23.6$ & 0.005 \\
\hline & & $9 \mathrm{mg} / \mathrm{mL}$ & $532 \pm 25.2$ & 0.282 \\
\hline & & $12 \mathrm{mg} / \mathrm{mL}$ & $561 \pm 22.4$ & 0.033 \\
\hline
\end{tabular}


TABLE I (continuation)

\begin{tabular}{|c|c|c|c|c|}
\hline ORGAN & COMPLEX & TREATMENT & $\begin{array}{c}\text { MEAN } \pm \text { SD } \\
(\mathrm{nmol} / \mathrm{min} \text { mg of proteins })\end{array}$ & $p$ \\
\hline \multirow{20}{*}{ LIVER } & I & CONTROL & $29.1 \pm 4.9$ & 1.00 \\
\hline & & $3 \mathrm{mg} / \mathrm{mL}$ & $30.6 \pm 4.2$ & 1.00 \\
\hline & & $6 \mathrm{mg} / \mathrm{mL}$ & $29.4 \pm 4.8$ & 1.00 \\
\hline & & $9 \mathrm{mg} / \mathrm{mL}$ & $30.6 \pm 4.9$ & 1.00 \\
\hline & & $12 \mathrm{mg} / \mathrm{mL}$ & $30 \pm 5.4$ & 1.00 \\
\hline & II & CONTROL & $8.2 \pm 1.1$ & 1.00 \\
\hline & & $3 \mathrm{mg} / \mathrm{mL}$ & $8.2 \pm 1.2$ & 1.00 \\
\hline & & $6 \mathrm{mg} / \mathrm{mL}$ & $7.7 \pm 1.1$ & 1.00 \\
\hline & & $9 \mathrm{mg} / \mathrm{mL}$ & $8.9 \pm 0.9$ & 1.00 \\
\hline & & $12 \mathrm{mg} / \mathrm{mL}$ & $7.1 \pm 0.9$ & 1.00 \\
\hline & III & CONTROL & $111.4 \pm 9.6$ & 1.00 \\
\hline & & $3 \mathrm{mg} / \mathrm{mL}$ & $124.4 \pm 10.4$ & 1.00 \\
\hline & & $6 \mathrm{mg} / \mathrm{mL}$ & $113.1 \pm 5.9$ & 1.00 \\
\hline & & $9 \mathrm{mg} / \mathrm{mL}$ & $113.8 \pm 10.8$ & 1.00 \\
\hline & & $12 \mathrm{mg} / \mathrm{mL}$ & $115.1 \pm 8.6$ & 1.00 \\
\hline & IV & CONTROL & $212.2 \pm 10.5$ & 1.00 \\
\hline & & $3 \mathrm{mg} / \mathrm{mL}$ & $218.3 \pm 12.8$ & 1.00 \\
\hline & & $6 \mathrm{mg} / \mathrm{mL}$ & $215.4 \pm 9.7$ & 1.00 \\
\hline & & $9 \mathrm{mg} / \mathrm{mL}$ & $221 \pm 10.3$ & 1.00 \\
\hline & & $12 \mathrm{mg} / \mathrm{mL}$ & $234.8 \pm 10.6$ & 1.00 \\
\hline
\end{tabular}

SD: Standard Deviation; 95\% Wald Confidence Interval.

understood. It is possible that the accumulation of toxic metabolites induces excessive formation of reactive species of oxygen and nitrogen (Fontella et al. 2000, Vargas et al. 2004, Barschak et al. 2008, Biancini et al. 2012).

Our study shown that GB3 statistically increase the activity of the complexes II and IV of ETC at different concentrations. However, the magnitude of this increase seems to be too low (less than $15 \%$ ) to present a physiologically importance. Besides, no alteration was observed in the activity of other enzymatic complexes in kidney homogenate, as well as, no changes in ETC activity were observed in cerebral cortex and liver. Once this is an in vitro study, it is possible that exposure time of these tissues to GB3 was not sufficient to cause changes, which does not rule out the possibility of finding other results in patient samples or cell culture exposed to GB3 in a chronic way.

Renal involvement in FD is one of the leading causes of death and disability in this condition, usually between the fourth and fifth decade of life. Patients are severely affected by renal disease requiring dialysis and even organ transplantation. In our studies, we observed an increase in SOD activity and in formation of reactive species in renal tissue homogenates in presence of GB3. These alterations can be related to the renal impairment commonly found in those affected by Fabry's disease (Germain 2010).

Tseng in a study with differentiated vascular endothelial cells found that excess accumulation of GB3 suppressed mitochondrial SOD expression and increased ROS production. We also verified that cortex homogenates exposed to GB3 showed a 
a

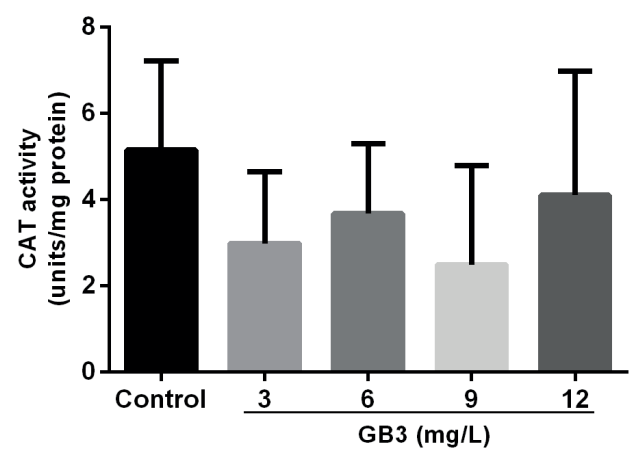

C

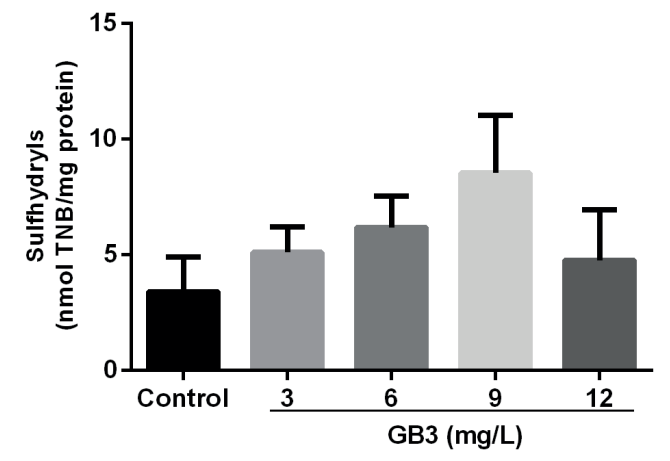

e

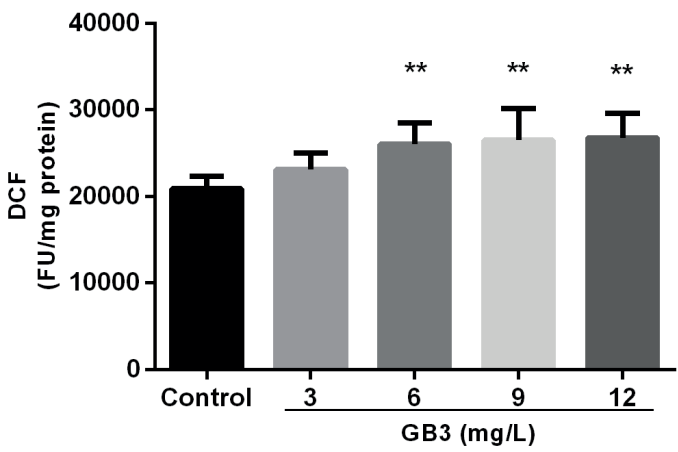

b

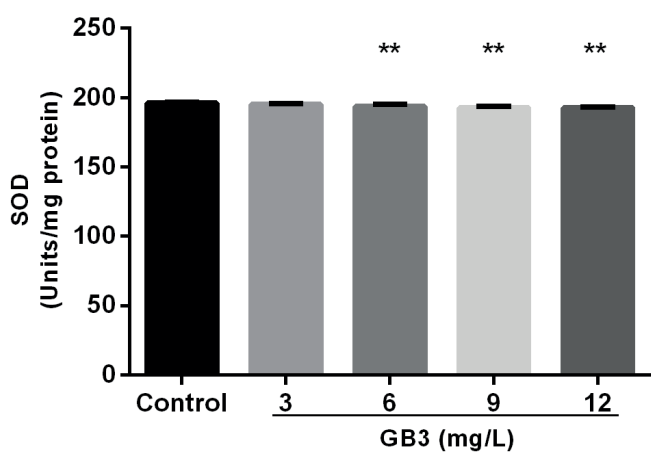

d

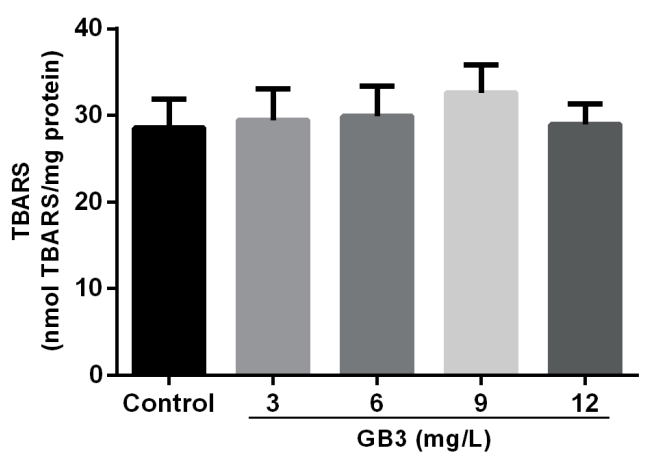

Figure 1 - In vitro effect of GB3 on catalase (CAT) activity (a), Superoxido dismutase (SOD) activity (b), sulfhydryl assay (c), lipoperoxidation (d) and production of reactive species (e) in cerebral cortex of Wistar rats. Values are means \pm S.D. $(n=6)$. Statistically significant differences from controls were determined by ANOVA followed by Tukey test: ** $\mathrm{p}<0.001$. 

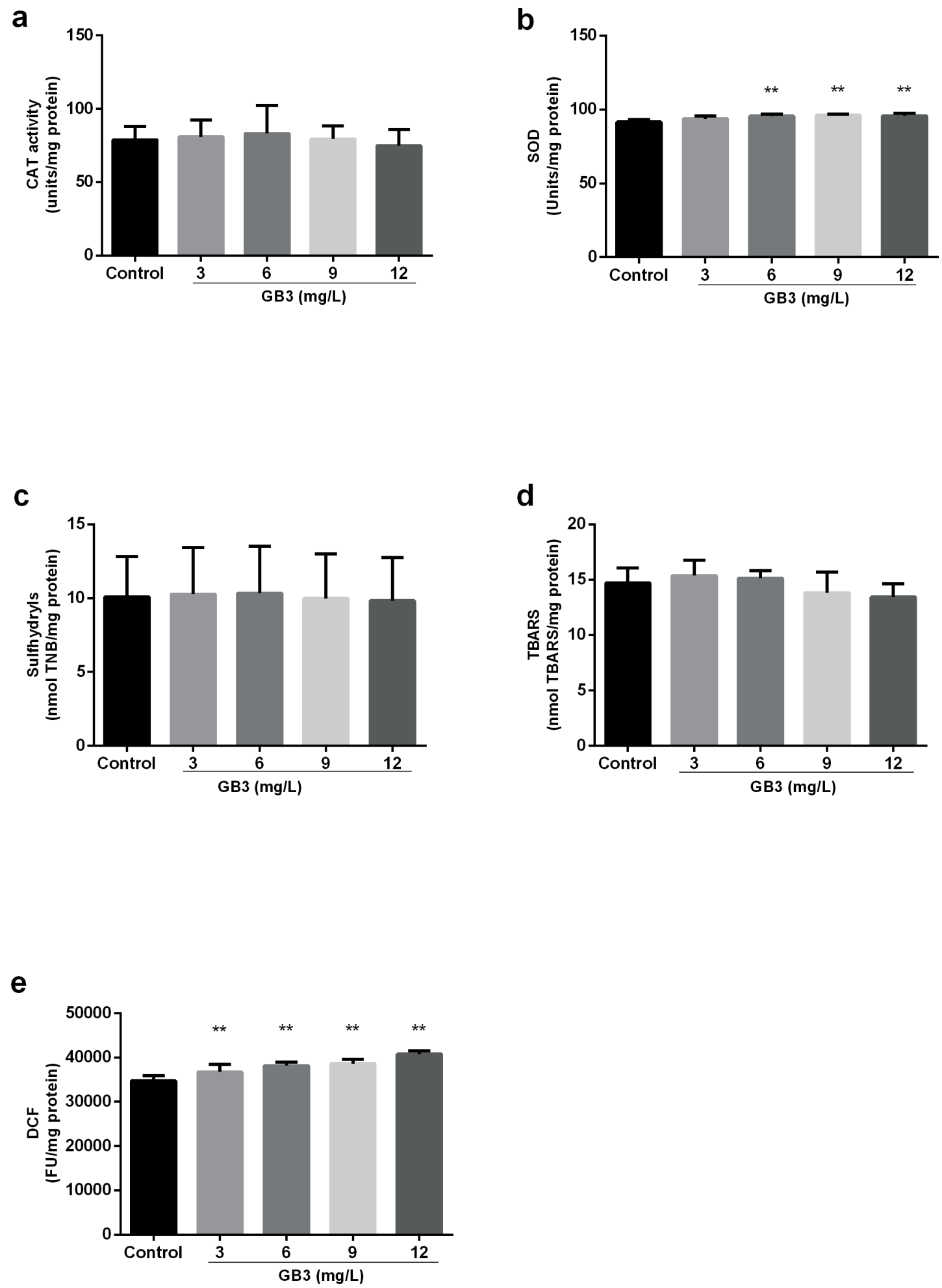

Figure 2 - In vitro effect of GB3 on catalase (CAT) activity (a), Superoxido dismutase (SOD) activity (b), sulfhydryl assay (c), lipoperoxidation (d) and production of reactive species (e) in kidney of Wistar rats. Values are means \pm S.D. $(\mathrm{n}=6)$. Statistically significant differences from controls were determined by ANOVA followed by Tukey test: $* * \mathrm{p}$ $<0.001$. 

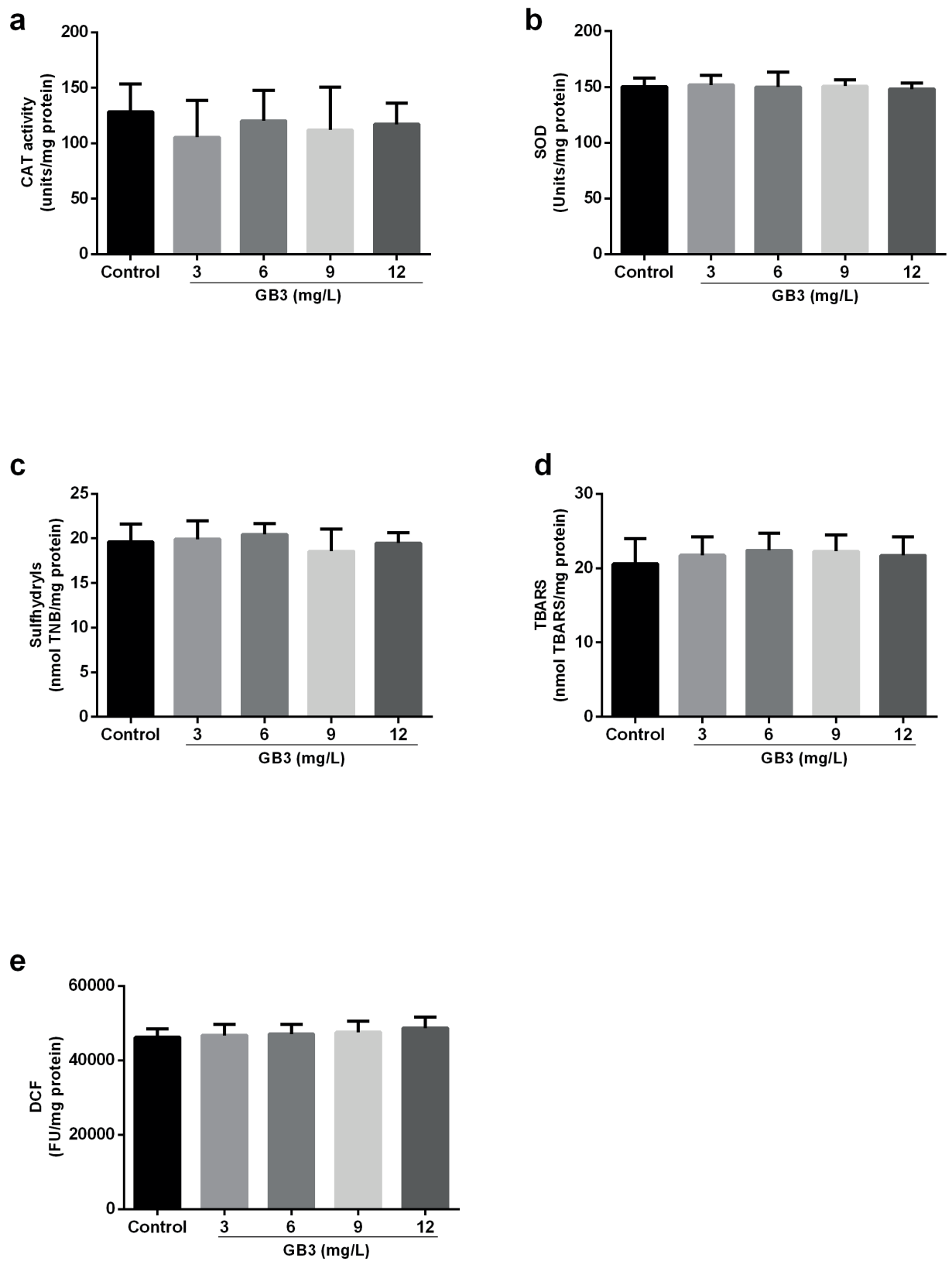

Figure 3 - In vitro effect of GB3 on catalase (CAT) activity (a), Superoxido dismutase (SOD) activity (b), sulfhydryl assay (c), lipoperoxidation (d) and production of reactive species (e) in liver of Wistar rats. Values are means \pm S.D. $(n=6)$.

decrease in the activity of the antioxidant enzyme SOD, suggesting a direct inhibition of the enzyme, and consequently an increase in the formation of reactive species by the presence of GB3 (Tseng 2017).

High ROS/RNS levels, when not neutralized by cellular antioxidant enzymes, induce redox imbalance that results in oxidative stress. This situation causes oxidative changes in the structure, function of cellular components, and can lead to the damage of cells, tissues and organs. Among cellular components, the most sensitive to oxidative modifications are membrane phospholipids. These are highly susceptible to oxidation and they are 
markers of oxidative damage (Niki 2009, Halliwell 2011).

Human tissues, in general, are susceptible to oxidative damage; however, the brain appears to be especially sensitive to this type of injury. One explanation for this would be the high consumption of oxygen and ATP presented by this tissue. In addition, the neuronal membranes present a large amount of lipids, sensitive to lipoperoxidation. Moreover, brain tissue has a low level of antioxidant defenses, which makes it even more sensitive to reactive species injury (Halliwell and Gutteridge 2007, Halliwell 2011).

Our collective results suggested that in vitro exposure to GB3 resulted in increase in production of reactive species and increase of antioxidant defenses in renal tissue. Furthermore, the presence of GB3 decreased antioxidant defenses in cerebral cortex and increase in production of reactive species. However, the effect of GB3 on ETC activity can be considered not relevant. Thus, we can conclude that the principal metabolite accumulated in FD, GB3, contribute in some way to redox imbalance and to cellular damage observed in this disease.

Our results do not allow ruling out the involvement of ETC on pathophysiology of FD disease. However, further studies involving ETC in Fabry patient samples or cell cultures may help to better understand these results and a better understanding of the biological processes and mechanisms that lead to renal dysfunction and disease progression suggesting additive treatment strategies in order to decrease the high morbidity of patients with Fabry.

\section{ACKNOWLEDGMENTS}

This work was supported by grants from the Conselho Nacional de Desenvolvimento Científico e Tecnológico (CNPq) and Fundação de Amparo à Pesquisa do Estado do Rio Grande do Sul (FAPERGS).

\section{AUTHOR CONTRIBUTIONS}

RM Alvariz and AG Barschak conceived and planned the experiments. RM Alvariz, ITDS Moreira and GK Cury carried out the experiments. RM Alvariz, CR Vargas and AG Barschak contributed to the interpretation of the results. RM Alvariz and AG Barschak took the lead in writing the manuscript. All authors provided critical feedback and contributed to the final version of the manuscript.

\section{REFERENCES}

AEBI H. 1984. Catalase in vitro. Methods Enzymol 105: 121126.

AKSENOV MY AND MARKESBERY WR. 2001. Change in thiol content and expression of glutathione redox system gene in the hippocampus and cerebellum in Alzheimer's disease. Neurosci Lett 302: 141-145.

BARSCHAK AG, SITTA A, DEON M, BARDEN AT, DUTRA-FILHO CS, WAJNER M AND VARGAS CR. 2008. Oxidative stress in plasma from maple syrup urine disease patients during treatment. Metab Brain Dis 23: 7180 .

BIANCINI GB ET AL. 2012. Globotriaosylceramide is correlated with oxidative stress and inflammation in Fabry patients treated with enzyme replacement therapy. Biochim Biophys Acta 1822: 226-232.

BIANCINI GB, JACQUES CE, HAMMERSCHMIDT T, DE SOUZA HM, DONIDA B, DEON M, VAIRO FP, LOURENÇO CM, GIUGLIANI R AND VARGAS CR. 2016. Biomolecules damage and redox status abnormalities in Fabry patients before and during enzyme replacement therapy. Clin Chim Acta 461: 41-46.

CHERRY AD AND PIANTADOSI CA. 2015. Regulation of mitochondrial biogenesis and its intersection with inflammatory responses. Antioxid Redox Signal 22: 965976.

DESNICK R, LANNOUYAND ENG C. 2001. $\alpha$-Galactosidase A deficiency: Fabry disease. The Metabolic and Molecular Bases of Inherited Disease. $8^{\text {th }}$ ed., McGraw-Hill Inc., New York, USA, p. 3733-3774.

FIGUEIRA TR, BARROS MH, CAMARGO AA, CASTILHO RF, FERREIRA JC, KOWALTOWSKI AJ, SLUSE FE, SOUZA-PINTO NC AND VERCESI AE. 2013. Mitochondria as a source of reactive oxygen and nitrogen species: from molecular mechanisms to human health. Antioxid Redox Signal 18: 2029-2074.

FONTELLA FU, PULROLNIK V, GASSEN E, WANNMACHER CM, KLEIN AB, WAJNER M 
AND DUTRA-FILHO CS. 2000. Propionic and L-methylmalonic acids induce oxidative stress in brain of young rats. Neuroreport 11: 541-544.

GERMAIN DP. 2010. Fabry disease. Orphanet J Rare Dis: 5-30.

HALLIWELL B. 2011. Free radicals and antioxidants - quo vadis? Trends Pharmacol Sci 32: 125-130.

HALLIWELL B AND GUTTERIDGE J. 2007. Free radicals in biology and medicine. $4^{\text {th }}$ ed., Oxford University Press, New York.

KRÜGER R, BRUNS K, GRÜNHAGE S, ROSSMANN H, REINKE J, BECK M AND LACKNER KJ. 2010. Determination of globotriaosylceramide in plasma and urine by mass spectrometry. Clin Chem Lab Med 48: 189198.

LEBEL CP AND BONDY SC. 1992. Oxidative damage and cerebral aging. Prog Neurobiol 38: 601-609.

LIEBERMAN M AND MARKS AD. 2009. Mark's Basic Medical Biochemistry, a Clinical Approach, Baltimore, Lippincott Williams \& Wilkins.

LOWRY OH, ROSEBROUGH NJ, FARR AL AND RANDALL RJ. 1951. Protein measurement with the folin phenol reagent. J Biol Chem 193: 265-275.

MISRA HP AND FRIDOVICH I. 1972. The role of superoxide anion in the autoxidation of epinephrine and a simple assay for superoxide dismutase. J Biol Chem 247: 3170-3175.

NELSON DL AND COX MM. 2013. Lehninger Principles of Biochemistry, W.H. Freeman and Company, New York, EUA, p. 691-722.
NIKI E. 2009. Lipid peroxidation: physiological levels and dual biological effects. Free Radic Biol Med 47: 469-484.

OHKAWA H, OHISHI N AND YAGI K. 1979. Assay for lipid peroxides in animal-tissues bythiobarbituric acid reaction. Analytical Biochemistry 95: 351-358.

POYTON RO, BALL KA AND CASTELLO PR. 2009. Mitochondrial generation of free radicals and hypoxic signaling. Trends Endocrinol Metab 20: 332-340.

SHEN JS, MENG XL, MOORE DF, QUIRK JM, SHAYMAN JA, SCHIFFMANN R AND KANESKI CR. 2008b. Globotriaosylceramide induces oxidative stress and upregulates cell adhesion molecule expression in Fabry disease endothelial cells. Mol Genet Metab 95: 163-168.

SPINAZZI M, CASARIN A, PERTEGATO V, SALVIATI L AND ANGELINI C. 2012. Assessment of mitochondrial respiratory chain enzymatic activities on tissues and cultured cells. Nat Protoc 7: 1235-1246.

TSENG WL ET AL. Imbalanced Production of Reactive Oxygen Species and Mitochondrial Antioxidant SOD2 in Fabry Disease-Specific Human Induced Pluripotent Stem Cell-Differentiated Vascular Endothelial Cells. Cell Transplant 26(3): 513-527.

VALKO M, LEIBFRITZ D, MONCOL J, CRONIN MT, MAZUR M AND TELSER J. 2007. Free radicals and antioxidants in normal physiological functions and human disease. Int J Biochem Cell Biol 39: 44-84.

VARGAS CR ET AL. 2004. Evidence that oxidative stress is increased in patients with X-linked adrenoleukodystrophy. Biochim Biophys Acta 1688: 26-32. 